\title{
KOMPETENSI KEPRIBADIAN GURU DALAM PERSPEKTIF PENDIDIKAN ISLAM
}

\author{
Ahmad Arifai \\ Sekolah Tinggi Ilmu Tarbiyah Raudhatul Ulum Sakatiga \\ Email: sugrhu@gmail.com
}

\begin{abstract}
Abstrak
Faktor terpenting dari seorang guru adalah kepribadiannya. Karena dengan kepribadian itulah seorang guru bisa menjadi seorang pendidik dan pembina bagi anak didiknya atau bahkan malah sebaliknya akan menjadi seorang perusak dan penghancur bagi masa depan anak didiknya. Kepribadian menjadi unsur yang turut menentukan keakraban guru dengan para peserta didiknya. Sebab, kepribadian inilah yang akan tercermin dalam sikap dan perkataan ketika membina dan membimbing anak-anak didiknya.

Pendidikan yang dilaksanakan oleh guru dalam proses pembelajaran di sekolah dan masyarakat memerlukan kompetensi dalam arti luas yaitu standar kemampuan yang diperlukan untuk menggambarkan kualifikasi seseorang baik secara kualitatif maupun kuantitatif dalam melaksanakan tugasnya. Kepribadian yang sesungguhnya adalah abstrak,sulit dilihat dan tidak bisa diketahui secara nyata, yang dapat diketahui hanyalah penampilan dari segiluarnya saja misalnya : dalam tindakannya, ucapannya, cara bergaul,berpakaian dan menghadapi persoalan atau masalah baik yang ringanatau yang berat. Kepribadian bukanlah sesuatu yang dapat dikenakan ataupun ditanggalkan sebagaimana orang mengenakan pakaian ataupun mengikuti gaya model tertentu. Kepribadian adalah tentang pribadi secara keseluruhan, kepribadian adalah sesuatu yang unik pada diri masing-masing individu.
\end{abstract}

Kata Kunci: Kompetensi, Guru, Kepribadian

\section{Pendahuluan}

Guru adalah orang yang terpelajar dan penentu masa depan. Ia merupakan seorang pendidik, pembimbing, dan pengarah yang bijaksana bagi masyarakat. Ahli-ahli pendidikan Islam juga pendidikan Barat telah sepakat bahwa tugas guru adalah mendidik. Mendidik adalah tugas yang amat luas. Mendidik itu dilakukan dalam bentuk mengajar, dalam bentuk dorongan, memuji, menghukum, memberi contoh membiasakan dan lain-lain. (Yustisia, 2008:35)

Sebagai teladan bagi peserta didik, seorang guru harus mempunyai sikap dan kepribadian utuh yang bisa dijadikan teladan bagi seluruh segi kehidupan. Oleh karena itu, seorang guru harus selalu berusaha untuk selalu memilih dan berprilaku yang baik agar bisa mengangkat citra dirinya sebagai guru yang baik.

Guru yang baik merupakan guru yang siap memberikan bimbingan yang terkait dngan ilmu pengetahuan dan prilaku terpuji terhadap peserta didiknya. Di 


\section{Kompetensi Kepribadian Guru dalam Perspektif Pendidikan Islam Ahmad Arifai}

sini, guru berperan sebagai partner yang siap melayani dan mengarahkan peserta didiknya menjadi pribadi yang lebih baik. Seorang guru merupakan sosok yang menjadi panutan bagi anak-anak. Dengan demikian, guru memang dituntut untuk mempunyai ilmu pengetahuan dan mengikuti perkembangan zaman agar bisa menyesuaikan dengan anak yang meneladaninya.

Guru tidak hanya sebatas pada mengajarkan keilmuan, tetapi juga mendidik dan mengajar tentang hal-hal yang berhubungan dengan spiritualitas dan keterampilan fisik. Jadi, dapat dikatakanbahwa guru adalah seseorang yang mempunyai tugas untuk berupaya mencerdaskan seluruh aspek dalam diri manusia. Aspek-aspek tersebut meliputi aspek emosional dan spritual, pengetahuan, dan keterampilan fisik. Oleh karena itu, guru bisa disebut sebagai unsur manusiawi yang ada dalam pendidikan. Ia merupakan sosok yangmenduduki posisi penting dan memegang peranan yang sangat vital dalam pendidikan.

Guru adalah spiritual father atau bapak rohani bagi seorang anak didik dalam memberikan santapan jiwa dengan ilmu pengetahuan akhlak. Untuk itu, setiap guru harus memiliki kepribadian yang baik dan terintegrasi, kepribadian yang baik ini tentu saja ditinjau dari segi murid, orang tua, dan dari segi kebutuhan tugasnya. Kepribadian seorang guru merupakan hal yang sangat penting, sebab kepribadian merupakan salah satu komponen penting yang dimiliki guru dalam melaksanakan tugas-tugasnya. Dengan kata lain, kepribadian bisa menjadi salah satu faktor yang menentukan berhasil atau tidaknya seorang guru dalam melaksanakan segala kewajibannya. Selain itu, kepribadian juga akan menjadi pembeda yang akan membedakan antara guru yang satu dengan guru yang lainnya.

Sikap guru hendaknya mengetahui dan menyadari betul akan peran dan kepribadiannya dalam mengajar sangat menentukan tercapai atau tidaknya tujuan pendidikan yang hendak dicapai dalam lembaga pendidikan, kepribadian guru dalam mengajar jauh lebih perlu mendapatkan perhatian yang serius. Karena disanalah seorang guru akan mewariskan segala tingkah laku dan sikap bawaan pada saat mengajar yang akan mempengaruhi anak didik pada perkembangan selanjutnya. Semua itu perlu dan penting untuk diperhatikan jika tujuan pembinaan di sekolah atau madrasah dalam pembinaan anak didiktersebut ingin tercapai.

Kepribadian adalah sesuatu yang berdiri, tetapi juga sesuatu yang terbuka terhadap dunia sekitarnya. Agama Islam mengenal istilah fitrah sebagai potensi dasar kejiwaan pembentuk kepribadian manusia, perkembangan fitrah itu diwarnai oleh pengaruh orang tua, pendidikan, masyarakat serta situasi, dan kondisi lingkungan. Pada orang Islam terdapat istilah konsep Insan kamil sebagai tujuan pembentukan, pengembangan, dan pembinaan kepribadian muslim. (Abu Ahmadi, 2000,153) Pendidikan Islam ialah bimbingan jasmani dan ruhani berdasarkan hukum-hukum agama Islam menuju terbentuknya kepribadian yang utama menurut ukuran-ukuran Islam. al-Qur'an sebagai sumber dari segala sumber hukum Islam hanyalah memuat prinsip-prinsip dasar ajaran Islam. Adapun sebagian ayatnya yang menguraikan prinsip-prinsip dasar tersebut secara rinci 
merupakan contoh dan petunjuk bahwa seluruh isi kandungan al-Qur'an masih perlu penjelasan.

Penjelasan al-Qur'an dapat dijumpai dalam sunnah rasul. Sunnah rasul itu merupakan cermin dari segala tingkah laku Rasulullah saw yang harus diteladani. Inilah salah satu alat pendidikan yang paling efektif dalam pembentukan pribadi. Implikasinya bahwa pendidikan Islam dalam Perencanaan, perumusan dan pelaksanaanya harus mengarah kepada pembentukan pribadi yang berakidah Islam, berakhlak mulia dan berpikiran bebas.

Realitas di masyarakat membuktikan bahwa pada saat ini belum seluruhnya guru memiliki kompetensi kepribadian guru yang sesuaidalam perspektif pendidikan Islam. Kenyataan ini dapat dicermati dengan melihat kondisi saat ini yang menunjukan masih banyaknya guru yang tidak mengerti tentang kompetensi kepribadian dalam perspektif Islam.

Sehingga menyebabkan banyak guru yang tidak disukai oleh anak didik di sekolah. Guru yang tidak disenangi oleh anak didik itu itu disebabkan oleh budi pekerti guru dalam pandangan anak didik tidak baik.

\section{PEMBAHASAN}

\section{Kompetensi Kepribadian Guru}

\section{Pengertian Kompetensi Kepribadian Guru}

\section{a. Pengertian Kompetensi}

Menurut Usman, kompetensi adalah suatu hal yang menggambarkan kualifikasi atau kemampuan seseorang, baik yang kualitatif maupun kuantitatif. (Kunandar,2007:51) Dari penjelasan tersebut dapat penulis simpulkan bahwa kompetensi adalah kemampuan yang betul-betul berkualitas yang dimiliki seseorang. Charles E. Johnson, mengemukakan bahwa kompetensi merupakan perilaku yang rasional untuk mencapai tujuan yang dipersyaratkan sesuai dengan kondisi yang diharapkan. Melihat dari pernyataan tersebut dapat penulis ambil kesimpulan bahwa kemampuan seseorang itu harus sesuai dengan situasi dan kondisi yang diinginkan oleh perkembangan zaman.

Kompetensi merupakan suatu tugas yang memadai atas kepemilikan pengetahuan, keterampilan, dan kemampuan yang dituntut oleh jabatan seseorang.(Roestiyah,2006:4) Dapat penulis simpulkan bahwa seseorang itu harus memiliki kemampuan yang baik sesuai dengan tuntutan profesi yang diinginkan. Kompetensi juga berarti pengetahuan, keterampilan dan nilai-nilai dasar yang direfleksikan dalam kebiasaan berpikir dan bertindak.

Kompetensi adalah kumpulan pengetahuan, prilaku, dan keterampilan yang harus dimiliki huru untuk mencapai tujuan pembelajaran dan pendidikan. Kompetensi diperoleh melalui pendidikan, pelatihan, dan belajar mandiri dengan memanfaatkan sumber belajar. Pemaknaan kompetensi dari sudut istilah mencakup beragam aspek, tidak hanya terikat dengan fisik dan mental, tetapi juga aspek 


\section{Kompetensi Kepribadian Guru dalam Perspektif Pendidikan Islam}

Ahmad Arifai

spiritual. Kompetensi terikat dengan kemampuan beradaptasi terhadap lingkungan kerja baru, di mana seseorang dapat menjalankan tugasnya dengan baik berdasarkan kemampuan yang dimilikinya.(Jejen, 2012:27)

Pengertian lainnya tentang kompetensi merujuk pada hasil kerja (out put), individu maupun kelompok. Kompetensi berarti kemampuan mewujudkan sesuatu sesuai dengan tugas yang diberikan kepada seseorang. Kompetensi terikat erat dengan standar, seseorang disebut kompeten dalam bidangnya jika pengetahuan, keterampilan, dan sikapnya, serta hasil kerjanya sesuai standar (ukuran) yang ditetapkan dan diakui oleh lembaganya/pemerintah. Di sisi lain, kompetensi merupakan tugas khususyang berarti hanya dapat dilakukan oleh orang-orang spesial/tertentu. Artinya, tidak bisa sembarang orang dapat melakukan tugas tersebut. Dari penjelasan tersebut dapat disimpulkan bahwa kompetensi merupakan kemampuan seseorang yang meliputi pengetahuan, keterampilan, dan sikap, yang dapat diwujudkan dalam hasil kerja nyata yang bermanfaat bagi diri dan lingkungannya.

\section{b. Pengertian Kepribadian}

Kepribadian merupakan predisposisi dalam perwujudan tingkah laku. Kepribadian dapat merupakan unsur bawaan sejak seorang dilahirkan, tetapi juga di bentuk dari unsur-unsur diluar diri. Menurut Allport, kepribadian adalah organisasi-organisasi dinamis yang sistem-sistem Psikofisik (rohani dan jasmani) dalam individu yang turut menentukan cara-caranya yang unik dan khas dalam menyesuaikan diri dan lingkungannya. Sedangkan menurut Kuncoroningrat, kepribadian adalah sebagai susunan unsur-unsur akal dan jiwa yang menentukan perbedaan tingkah laku atau tindakan dari tiap-tiap individu manusia.. (Alexsobur, 2003:301)

Menurut Raymond Bernard Cattell, kepribadian adalah sesuatu yang memungkinkan prediksi tentang apa yang akan dikerjakan seseorang dalam situasi tertentu. Kepribadian mencakup semua tingkah laku individu, baik yang terbuka (lahiriah) maupun tersembunyi (batiniah).

Dengan kata lain dapat dikatakan kepribadian yang mencakup semua aktualisasi dari (penampilan) yang selalu tampak pada diri seseorang, merupakan bagian khas atau ciri dari seseorang. Misalnya ada orang yang memiliki sifat pemarah tapi jujur, tekun bekerja, suka menolong, senang berola raga, suka berpakaian sederhana dan sebagainya. Di pihak lain, ada orang yang memiliki sifat penyabar, tenang, tekun bekerja tapi tidak suka bergaul, pendiam,pelit dan sebagainya. Pola-pola sifat, kebiasaan, kegemaran, dan sebagainya dikemukakan di atas adalah contoh pola/bentuk kepribadian seseorang.

\section{c. Pengertian Kompetensi Kepribadian Guru}

Dalam UU Nomor 14 Tahun 2015tentang Guru dan Dosen pasal 1 disebutkan bahwa, "Kompetensi adalah seperangkat pengetahuan, keterampilan, dan prilaku 
P-ISSN : 2541-3686

yang harus dimiliki, dihayati, dan dikuasai oleh guru atau dosen dalam melaksanakan dalam tugas keprofesionalan". "Guru adalah pendidik profesional dengan tugas mendidik, mengajar, membimbing, mengarahkan, melatih, menilai, dan mengevaluasi peserta didik pada pendidikan anak usia dini jalur pendidikan formal, dasar, dan menengah". Jadi kompetensi guru adalah seperangkat kemampuan yang ada dalam diri guru agar dapat mewujudkan kinerjanya secara tepat dan efektif.

Dalam perspektif kebijakan nasional, pemerintah telah merumuskan empat jenis kompetensi guru, sebagaimana tercantum dalam penjelasan peraturan pemerintah No. 19 tahun 2005 tentang Standar Nasional Pendidikan, yaitu: kompetensi pedagogis, kepribadian, sosial dan profesional.

1) Kompetensi Pedagogis

Adalah kemampuan dalam pengelolaan peserta didik yang meliputi: pemahaman dalam pengelolaan peserta didik yang meliputi: pemahaman wawasan atau landasan kependidikan; pemahaman tentang peserta didik; pengembangan kurikulum/silabus; perencanaan pembelajaran; pelaksanaan pembelajaran yang mendidik dan diologis; evaluasi hasil belajar dan penggembangan peserta didik untuk mengaktualisasikan potensi yang dimilikinya.

2) Kompetensi Kepribadian

Kemampuan kepribadian mencakup kepribadian utuh, berbudu luhur, jujur, dewasa, beriaman, bermoral; kemampuan mengaktualisasikan diri seperti disiplin, tanggung jawab, peka, objektif, luwes, berwawasan luas, dapat berkomunikasi dengan orang lain; kemampuan menggembangkan profesi seperti berpikir kreatif, refleksi, mau belajar sepanjang hayat, dan dapat mengambil keputusan. Kemampuan kepribadian ebih menyangkutjati diri seorang guru seperti pribadi yang baik, tanggung jawab, terbuka dan terus menerus mau belajar untuk maju.

3) Kompetensi Sosial

Kompetensi sosial merupakan kemampuan pendidik sebagai bagian dari masyarakat untuk berkomunikasi dengan lisan dan tulisan; menggunakan teknologi komunikasi dan informasi secara fungsional; bergaul secara efektif peserta didik,sesama pendidik, tenaga pendidik, orangtua/wali peserta didik; dan bergaul secara santun dengan masyarakat sekitar.

\section{4) Kompetensi Profesional}

Kemampuan penguasaan materi pembelajaran secara luas dan mendalam yang meliputi konsep, struktur, dan metode keilmuan teknologi/seni yang menaungi/ kahoren dengan materi ajar; materi ajar yang ada dalam kurikulum sekolah; hubungan konsep antarmata pelajaran yang terkait; penerapan konsep keilmuan dalam kehidupan sehari-hari; dan kompetisi secara profesional dalam konteks global dengan tetap melestarikan nilai dan budaya nasional.

Setiap guru mempunyai pribadi masing-masing sesuai ciri- ciripribadi yang mereka miliki. Ciri-ciri inilah yang membedakan seorang guru dariguru lainnya. Kepribadian sebenarnya adalah suatu masalah yang abstrak, hanyadapat dilihat 


\section{Kompetensi Kepribadian Guru dalam Perspektif Pendidikan Islam}

Ahmad Arifai

lewat penampilan, tindakan, ucapan, cara berpakaian dan dalam menghadapi setiap persoalan. Kepribadian adalah unsur yang sangat menentukan keakraban hubungan guru dengan anak didik. Kepribadian guru tercermin dalam sikap danperbuatannya dalam membina dan membimbing anak didik.

Sebagai teladan, guru harus memiliki kepribadian yang dapat dijadikan profil idola, sehingga seluruh aspek tingkah lakunya adalah figur yang paripurna. Jadi, kompetensi kepribadian guru adalah kemampuan kepribadian yang harus dimiliki seorang pendidik, yaitu bahwa guru hendaknya memiliki kepribadian yang mantap dan stabil, dewasa, arif, dan berakhlak mulia. Di dalamnya juga diharapkan tumbuhnya kemandirian guru dalam menjalankan tugas serta senantiasa terbiasa membangun etos kerja. Hingga semua sifat ini memberikan pengaruh positif terhadap kehidupan guru dalam kesehariannya.

\section{Kompetensi Kepribadian yang harus dimiliki oleh Guru}

Dalam Peraturan Menteri Pendidikan Nasional No. 16 Th. 2007 kompetensi kepribadian guru mencakup lima subkompetensi, yaitu kepribadian yang mantap dan stabil, dewasa, arif, berwibawa, dan berakhlak mulia. (Sudarman, 2010:203) Subkompetensi kepribadian yang mantap dan stabil adalah bertindak sesuai dengan norma hukum, sesuai dengan norma sosial,dan sebagai guru memiliki konsistensi dalam bertindak sesuai dengan norma.

Subkompetensi kepribadian yang dewasa memiliki indikator: menampilkan kemandirian dalam bertindak sebagai pendidik dan memiliki etos kerja sebagai guru. Subkompetensi kepribadian yang arif memiliki indukator : menampilkan tindakan yang didasarkan pada kemanfaatan peserta didik, sekolah, dan masyarakat serta menunjukan keterbukaan dalam berpikir dan bertindak.

Subkompetensi kepribadian yang berwibawa memiliki indikator : memiliki prilaku yang berpengaruh positif terhadap peserta didik dan memiliki prilaku yang disegani. Subkompetensi kepribadian akhlak mulia dapat menjadi teladan memiliki indikator : bertindak sesuai dengan norma Agama (iman dan takwa, jujur, ikhlas, suka menolong), dan memiliki prilaku yang diteladani peserta didik.

\section{Pendidikan Islam}

\section{Pengertian Pendidikan Islam}

Pengertian pendidikan secara etimologi berasal dari bahasa Romawi educare, yaitu mengeluarkan dan menuntun, tindakan merealisasikan potensi anak yang dibawa waktu dilahirkan di dunia. Secara sederhana istilah "Pendidikan Islam" dapat dipahami dalam beberapa kajian berikut:

1. Pendidikan menurut Islam atau pendidikan islami yakni pendidikan yang dipahami dan dikembangkan dari ajaran dan nilai-nilai fundamental yang terkandung dalam sumber dasarnya yaitu al-Qur'an dan as-Sunnah. 
Volume 3 Nomor 1 Edisi Juni 2018

P-ISSN : 2541-3686

2. Pendidikan keislaman atau Pendidikan Agama Islam, yakni upaya membedakan agama Islam atau ajaran Islam dan nilai-nilainya agar menjadi way of life (pandangan dan sikap hidup).

3. Pendidikan dalam Islam atau proses praktik penyelenggaraan pendidikan yang berlangsung dan berkembang dalam sejarah umat Islam dalam arti proses bertumbuhkembangnya Islam dan umatnya.(Bashori, 2009:9)

Istilah pendidikan dalam konteks Islam pada umumnya mengacu kepada term al-tarbiyah, al-ta'dib, dan al-ta'lim. Dari ketiga istilah tersebut term yang populer digunakan dalam praktek pendidikan Islam ialah term al-tarbiyah. Sedangkan term al-ta'dib dan al-ta'lim jarang digunakan. Padahal kedua istilah tersebut telah digunakan sejak awal pertumbuhan Pendidikan Islam.

a. Istilah al-tarbiyah

Pengunaan istilah al-tarbiyah berasal dari kata Rabb. Walaupun kata ini memiliki banyak arti, akan tetapi pengertian dasarnya menunjukan makna tumbuh, berkembang, memelihara, merawat, mengatur, menjaga kelestarian dan eksistensinya.

Kata Rabb sebagaimana terdapat Q.S Al Fatihah 2/1(alhamdu lillaahi rabb al'alamin) mempunyai kandungan makna yang berkonotasi dengan istilah al-Tarbiyah sebab kata Rabb (Tuhan) dan murabbi (pendidik) berasal dari akar kata yang sama. Berdasarkan hal ini, maka Allah adalah pendidik yang Maha Agung bagi seluruh alam semesta.

Uraian di atas, secara filosofis mengisyaratkan bahwa proses pendidikan Islam adalah bersumber pada pendidikan yang diberikan Allah sebagai 'pendidik' seluruh ciptaan-Nya, termasuk manusia. Dalam konteks yang luas, pengertian pendidikan Islam yang dikandung dalam term al-tarbiyah terdiri atas empat unsur pendekatan, yaitu: 1) memelihara dan menjaga fitrah anak didik menjelang dewasa (baligh). 2) mengembangkan seluruh potensi menuju kesempurnaan. 3) mengarahkan seluruh fitrah menuju kesempurnaan. 4) melaksanakan pendidikan secara bertahap. (Rasyid, 2005:206)

\section{b. Istilah al-Ta'lim}

Istilah al-Ta'lim telah digunakan sejak priode awal pelaksanaan pendidikan Islam. Menurut para ahli, kata ini lebih bersifat universal di banding dengan alTarbiyah dan al-Ta'dib. Rasyid Ridla, misalnya mengartikan al-Ta'lim sebagai proses transmisi berbagai ilmu pengetahuan pada jiwa individu tanpa adanya batasan dan ketentuan tertentu.

Ta'lim merupakan kata benda buatan (masdar) yang berasal dari kata 'allama, yang artinya pengajaran, mengajar, menjadikan yakin dan mengetahui. Ta'lim mencakup aspek-aspek pengetahuan dan keterampilan yang dibutuhkan seseorang dalam hidupnya serta pedoman prilaku yang baik. Dan merupakan suatu proses yang terus menerus diusahakan manusia semejak lahir sebab manusia dilahirkan tidak mengetahui sesuatu apapun. 


\section{Kompetensi Kepribadian Guru dalam Perspektif Pendidikan Islam}

\section{Ahmad Arifai}

\section{c. Istilah $a l-T a^{\prime} d i b$}

Kata al-Ta'dib secara etimologis adalah bentuk masdar yang berasal dari akar kata addaba. Yang artinya membuat makanan, melatih dengan akhlak yang baik, sopan santun dan tata cara pelaksanaan sesuatu yang baik.

$a l-T a^{\prime} d i b$ sebagai upaya pembentukan adab (tata krama), terbagi atas empat macam: 1) Ta'dib adab al-haqq, pendidikan tata krama spiritual dan kebenaran, yang memerlukan pengetahuan tentang wujud kebenaran, yang di dalamnya segala yang ada memiliki kebenaran tersendiri dan dengannya segala sesuatu yang diciptakan. 2) Ta'dib adab al-khidmah, pendidikan tata krama spiritual dalam pengabdian. 3) $T a^{\prime} d i b$ adab al-syariah, pendidikan tata krama spiritual dalam perekonomian. 4) $T a^{\prime} d i b$ adab al-shuhbah, pendidikan tata krama spiritual dalam persahabatan, berupa saling menghormati dan berprilaku mulia diantara sesama.

Istilah tarbiyah, $t a^{\prime} d i b$, dan ta'limbila ditinjau dari penekanannya terdapat perbedaan satu sama lain, namun apabila dilihat dari unsur kandungannya, terdapat keterkaitan kandungannya yang saling mengikat satu sama lain yakni dalam hal memelihara dan mendidik anak didik. Dalam $t a^{\prime} d i b$, titik tekannya adalah pada penguasaan ilmu yang benar dalam diri seseorang agar menghasilkan kemantapan amal dan tingkah laku yang baik.

Konsep al-Tarbiyah, titik tekannya difokuskan pada bimbingan anak supaya berdaya (punya potensi) dan tumbuh kelengkapan dasarnya serta dapat berkembang secara sempurna yaitu pengembangan ilmu dalam diri manusia dan penumpukan akhlak yakni pengalaman ilmu yang benar dalam mendidik pribadi. Adapun $\mathrm{ta}^{\prime} \mathrm{lim}$, titik tekannya adalah penyampaian ilmu pengetahuan yang benar, pemahaman, pengertian, tanggung jawab dan penanaman amanah pada anak. Ta'lim mencakup aspek-aspek pengetahuan dan keterampilan yang dibutuhkan seseorang seseorang dalam hidupnya dan pedoman prilaku yang baik.

Dalam pendidikan Islam selain kata al-tarbiyah, al-ta'lim, dan al-ta'dib sangat sering didengar dan digunakan. Tatapi, jika ditelusuri ayat-ayat al-Qur'an dan matan as-Sunah secara mendalam dan komprehensif sesungguhnya masih terdapat katakata lain yang berhubungan dengan pendidikan. Kata-kata lain tersebut, yaitu altazkiyah, al-muwa'idzah, al-tafaqqul, al-tahzib, al-irsyad, dan al-tabyin.

a. Al-tazkiyah

Al-tazkiyah berasal dari kata zakka-yazakki-tazkiyatan yang berarti purification (pemurnian atau pembersihan), chastening (kesucian dan kemurnian) pronouncement of (pengumuman atau pernyataan) integrity or credibility (ketulusan hati, kejujuran atau dapat dipercaya), attestation of a witness (pengesahan atau kesaksian), honorable record (catatan yang dapat dipercaya dan dihormati). Di dalam al-Qur'an, kata altazkiyah antara lain dapat dijumpai pada surat al-Jumu'ah ayat 2:
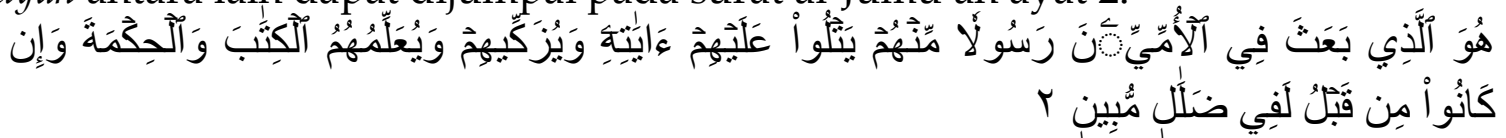
P-ISSN : 2541-3686

artinya: "Dialah yang mengutus kepada kaum yang buta huruf seorang Rasul di antara mereka, yang membacakan ayat-ayat-Nya kepada mereka, mensucikan mereka dan mengajarkan mereka Kitab dan Hikmah (As Sunnah). Dan sesungguhnya mereka sebelumnya benar-benar dalam kesesatan yang nyata."

Kata yuzakkihim (mensucikan mereka) pada ayat tersebut menurut H.M Quraish Shihab, dapat diidentikan dengan mendidik, sedangkan mengajar tidak lain kecuali mengisi benak anak didik dengan pengetahuan yang berkaitan dengan alam metafisika serta fisika. Kata al-tazkiyah atau yazakki telah digunakan para ahli dalam hubungannya dengan menyucikan atau pembersih jiwa seseorang dari sifat-sifat yang buruk (al-takhalli), dan mengisinya dengan akhlak yang baik (al-tahalli), sehingga melahirkan manusia yang memiliki kepribadian dan akhlak yang terpuji. Dalam hubungan ini, Ibn Sina dan al-Ghazali menggunakan istilah tazkiyah al-nafs (menyucikan diri) dalam arti membersihkan rohani dari sifat-sifat yang tercela.

Dari penjelasan tersebut penulis melihat bahwa kata al-tazkiyah ternyata juga digunakan untuk arti pendidikan yang bersifat pembinaan mental spiritual dan akhlak mulia.

b. Al-Wa'dz atau Al-Mau'idzah

Al-wad'z berasal dari kata wa'aza yang berarti to preach (mengajar), conscience (kata hati, suara hati, hati nurani), to admonish (memperingatkan atau mengingatkan), exhort (mendesak), dan to warn (memperingatkan). Dengan berbagai variasi, kata Al-wad'z dalam al-Qur'an diulang sebanyak 28 kali. Misalnya pada surat Luqman (31) ayat 13:

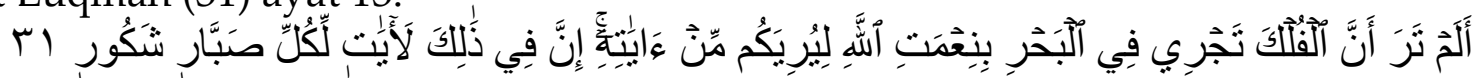
artinya:Dan (ingatlah) ketika Luqman berkata kepada anaknya, di waktu ia memberi pelajaran kepadanya: "Hai anakku, janganlah kamu mempersekutukan Allah, sesungguhnya mempersekutukan (Allah) adalah benar-benar kezaliman yang besar"

Dengan demikian, inti al-wa'dz atau al-mauidzah adalah pendidikan dengan cara memberikan penyadaran atau pencerahan batin, agar timbul kesadaran untuk berubah menjadi orang yang baik.

c. Al-Tafaqquh

Kata al-tafaqquh berasal dari kata tafaqqaha yatafaqqohu tafaqquhan, yang berarti mengerti, dan memahami. Dalam al-Qur'an, kata al-tafaqquh diulang sebanyak 20 kali, terdapat dalam suratat-Taubah ayat : 122

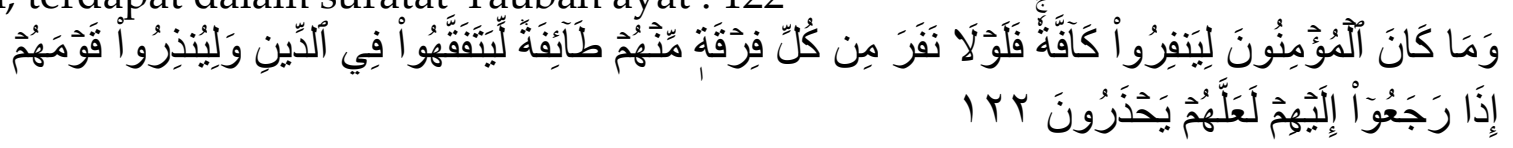

Artinya: "Tidak sepatutnya bagi mukminin itu pergi semuanya (ke medan perang). Mengapa tidak pergi dari tiap-tiap golongan di antara mereka beberapa orang untuk memperdalam pengetahuan mereka tentang agama dan untuk 


\section{Kompetensi Kepribadian Guru dalam Perspektif Pendidikan Islam}

\section{Ahmad Arifai}

memberi peringatan kepada kaumnya apabila mereka telah kembali kepadanya, supaya mereka itu dapat menjaga dirinya."

Kata al-tafaqquh selanjutnya lebih digunakan untuk menunjukan pada kegiatan pendidikan dan pengajaran ilmu agama Islam. Masyarakat yang mendalami ilmu agama di pesantren-pesantren di Indonesia misalnya, sering menyebut sedang melakukan al-tafaqquhfi al-din, yakni mendalami ilmu agama, sehingga menjadi ahli ilmu agama yang mumpuni yang selanjutnya disebut ulama, kiai, ajengan, buya, syekh, dan sebagainya.

\section{d. Al-Tahdzib}

Kata al-tahdzib secara harfiah berarti pendidikan akhlak, atau menyucikan diri dari perbuatan akhlak yang buruk, dan berarti pula terdidik atau terpelihara dengan baik, dan berarti pula beradab sopan. Al-tahdzib adalah expurgation (menghilangkan bagian-bagian atau kata-kata yang tidak patut), emendation (perbaikan atau perubahan), dan education (pendidikan). Dari berbagai pengertian tersebut, tampak bahwa secara keseluruhan kata al-tahdzib terkait dengan perbaikan mental spiritual, moral dan akhlak, yaitu memperbaiki mental seseorang yang tidak sejalan dengan ajaran atau norma, memperbaiki prilakunya agar menjadi baik dan terhormat, serta memperbaiki akhlak dan budi pekertinya agar menjadi berakhlak mulia.

\section{e. Al-irsyad}

Kata al-irsyad dapat mengandung arti menunjukkan, guidance (bimbingan), conducting (melakukan sesuatu), dan advising (nasehat). Dari sekian pengertian yang berhubungan dengan pengajaran dan pendidikan, yaitu bimbingan, pengarahan, nasihat dan bimbingan spiritual. Dengan demikian, kata al-irsyad layak dipertimbangkan untuk dimasukkan ke dalam arti kata pendidikan dan pengajaran.

\section{f. Al-Tabyin}

Kata al-tabyin berasal dari kata bayyana, yubayyinu, tabyinan yang mengandung arti exposition (mengemukakan), demonstration (mempertunjukkan), explanation (penjelasan), dan illustration (penggambaran), dan berarti juga menyatakan atau menerangkan. Berbagai kegiatan yang terkandung dalam arti al-tabyinini berkaitan dengan kegiatan pengajaran dan pendidikan. Karena itu, al-tabyin juga dapat berarti pendidikan dan pengajaran.

Lebih spesifik defenisi pendidkan Islam menurut para ahli pendidikan di antaranya adalah sebagai berikut, menurut Muhaimin, "pendidikan Islam ada dua. Yang pertama, pendidikan Islam merupakan aktivitas pendidikan yang diselenggarakan atau didirikan dengan hasrat dan niat mengejawantahkan ajaran nilai-nilai Islam. Yang kedua, pendidikan Islam adalah sistem pendidikan yang dikembangkan dari semangat atau dijiwai oleh ajaran dan nilai-nilai Islam". Dari kedua pengertian pendidikan Islam tersebut, maka pengertian pertama lebih menekankan aspek kelembagaan dan program pendidikan Islam, yang kedua lebih menekankan pada aspek ruh dan spirit Islam yang melekat pada setiap aktivitas pendidikan. 
Menurut H.M Arifin, "pendidikan Islam adalah suatu sistem kependidikan yang mencakup seluruh aspek kehidupan yang dibutuhkan oleh hamba Allah, sebagaimana Islam telah menjadi pedoman bagi seluruh aspek kehidupan manusia, baik duniawi maupun ukhrawi." Dari defenisi tersebut, nampak luas jangkauan pendidikan Islam, maka pendidikan Islam harus bersifat akomodatif terhadap tuntunan kemajuan zaman dengan tidak keluar dari acuan norma-norma kehidupan Islam. Menurut Abuddin Nata, "pendidikan Islam adalah upaya membimbing, mengarahkan, dan membina peserta didik yang dilakukan secara sadar dan terencana agar terbina suatu kepribadian yang utama sesuai dengan nilai-nilai ajaran Islam."

Dari beberapa pengertian pendidikan Islam di atas, dapatlah penulis menyimpulkan bahwa, pendidikan Islam merupakan suatu proses pembinaan generasi muda dalam menjalankan kehidupan, memenuhi tujuan hidupnya sesuai dengan kaidah-kaidah Islam dan untuk mencapai kehidupan ukhrawi yang bahagia.

\section{Simpulan}

Kompetensi guru adalah seperangkat kemampuan yang ada dalam diri guru agar dapat mewujudkan kinerjanya secara tepat dan efektif, seperti mempunyai kompetensi pedagogis, kepribadian, sosial dan profesional. Kepribadian adalah seluruh sifat dan watak yang tampak pada diri seseorang, seperti memiliki sifat jujur, sabar, pemarah, disiplin, egois dan pendiam. Kompetensi kepribadian guru mencakup lima subkompetensi, yaitu kepribadian mantap dan stabil, dewasa, arif, berwibawa dan berakhlak mulia.

Kompetensi dalam perspektif Islam terdiri dari kompetensi personal-religius, sosial-religius, dan profesional-religius. Kompetensi kepribadian guru dalam perspektif pendidikan Islam adalah kemampuan yang harus dimiliki guru dengan kepribadian utama (insan kamil) agar bisa dijadikan panutan oleh anak didik, sebab kemampuan dan akhlak yang baik dari guru bisa menjadi contoh yang akan digugu dan ditiru. Oleh sebab itu, sebagai guru yang baik wajib untuk menjadi teladan yang baik bagi anak didik. seperti mempunyai sifat disiplin, bertanggung jawab, jujur dan lain-lain. Dan pada intinya, kompetensi kepribadian guru dalam perspektif pendidikan Islam haruslah selalu mencontoh sifat dan prilaku Nabi yang tertera dalam al-Qur'an dan hadist. 


\section{Kompetensi Kepribadian Guru dalam Perspektif Pendidikan Islam}

Ahmad Arifai

\section{DAFTAR PUSTAKA}

Arifin, 2003. Ilmu Pendidikan IslaM, Jakarta: Bumi Aksara.

Abuddin Nata, 2004. Metodologi Studi Islam, Jakarta: Raja Grafindo Persada.

Muhaimin, 2009. Rekonstruksi Pendidikan Islam, Jakarta: Raja Grafindo Persada.

Abdul Mujib, 2006. Ilmu Pendidikan Islam, Jakarta:Kencana Pernada Media.

Ridwan Nasir,2005. Mencari Tipologi Format Pendidikan Ideal, Pondok Pesantren di Tengah Arus Perubahan, Yogyakarta: Pustaka Pelajar.

Piet A. Sahertian dan Ida Alaida sahertian, 2005. Supervisi pendidikan, Jakarta: Rineka Cipta.

Yustisia, 2008. hypno Teaching, Yogjakarta: Ar-Ruzz Media

Abu Ahmadi dan Munawar Sholeh, 2000. Psikologi Perkembangan, Jakarta : Rineka Cifta.

Abidin Ibnu Rusn, Pemikiran Al-Ghazali Tentang Pendidikan, Yogyakarta:Pustaka Pelajar,.

Roestiyah N.K, 2006. Masalah-masalah Ilmu Keguruan, Jakarta: Bina Aksara. 